\title{
Copper metabolism in American retinitis pigmentosa patients
}

\author{
MICHAEL F. MARMOR, ${ }^{1}$ JOHN W. NELSON, ${ }^{2}$ AND ALAN S. LEVIN ${ }^{2,3}$ \\ From the ${ }^{1}$ Division of Ophthalmology, Stanford University and the Ophthalmology Section, Veterans \\ Administration Hospital, Palo Alto; ${ }^{2}$ MML/Solano Laboratory, Berkeley; ${ }^{3}$ Department of Dermatology, \\ University of California, San Francisco
}

SUMMARY Serum copper, serum caeruloplasmin, and urinary copper excretion were measured in 38 American patients (and 15 family members) with recessive, dominant, and X-linked forms of retinitis pigmentosa. No abnormalities were found, in contrast to the findings of a recent study on Indian patients. Our data argue against a role for copper metabolism in ordinary retinitis pigmentosa.

Gahlot et al. (1976) recently described the findings of an abnormally low caeruloplasmin and an abnormally high urinary excretion of copper in retinitis pigmentosa patients from India. Their report suggested that retinitis pigmentosa might be a systemic disorder of copper metabolism, possibly because copper is involved in the formation of pigment.

We have measured these same systemic copper parameters in 38 American patients with several genetic forms of retinitis pigmentosa and in an associated group of $\mathbf{1 5}$ family members. We have failed to observe any similar abnormalities. We also question whether pigment metabolism is likely to be involved in the genesis of this disease.

\section{Subjects and methods}

The patients and family members were associated with the San Francisco Bay Area Chapter of the National Retinitis Pigmentosa Foundation; they had heard of the Indian study and were interested in obtaining copper studies. One of us (MFM) suggested that the tests be co-ordinated through a single laboratory to provide a consistent set of data.

All patients carried the general diagnosis of retinitis pigmentosa, and this had been confirmed by a variety of ophthalmologists in the area. Many patients had had electroretinograms, but no attempt was made to compile clinical information on each individual. Most had conventional disease with typical fundus changes, but some had variants such

Address for reprints: Dr Michael F. Marmor, Ophthalmology Section (112B1), Veterans Administration Hospital, 3801 Miranda Avenue, Palo Alto. CA 94304, USA as 'rod-cone dystrophy' or 'centro-peripheral retinitis pigmentosa'. Because we thought abnormal findings might be associated with a subgroup of the disease we did not wish to narrow the definition excessively. However, patients with other discrete disorders such as Laurence-Moon-Biedl syndrome, macular Stargardt's disease, fundus albipunctatus, etc, were excluded.

Blood studies were performed on a total of 40 patients, 17 family members, and 10 unrelated normal controls. However, the results from 2 female patients, 2 female family members, and 1 female control were eliminated from the final tabulation because their copper and caeruloplasmin values were markedly elevated (see 'Results'). All patients were asked about family history. Some came from clearly dominant or X-linked pedigrees. Those with no family history of disease (the majority) and those with only affected siblings or distant relatives were grouped as 'recessive'.

\section{BIOCHEMICAL STUDIES}

All chemical analyses were performed at the MML/ Solano Laboratory in Berkeley, California. Blood was drawn at affiliated laboratories with the use of identical technique and glassware. Samples were spun down within 1 hour after being drawn, and the serum was frozen for transfer to the central laboratory.

Serum copper was measured by the method of Beale and Croft (1964). Serum caeruloplasmin was measured by both an immunodiffusion technique (M-Partigen plate, Behring Diagnostics), and by the chemical determination of copper oxidase activity (O'Brien et al., 1968). Urinary excretion of copper was measured by collecting 24 -hour samples 
in copper-free containers and determining the copper content by the method of Beale and Croft (1964).

\section{Results}

SERUM COPPER VALUES

Table 1 compares the serum copper and caeruloplasmin of patients with retinitis pigmentosa, unaffected family members, and (for caeruloplasmin) unrelated controls. All of these values fell within the normal range. There were no major differences between patients and family members, and both

Table 1 Serum copper values

\begin{tabular}{|c|c|c|c|c|}
\hline & \multirow[b]{2}{*}{$\begin{array}{l}\text { f.ge } \\
\text { (Mean/ } \\
\text { range) }\end{array}$} & \multirow[b]{2}{*}{$\begin{array}{l}\text { Copper }{ }^{1} \\
(u g / 100 \mathrm{ml})\end{array}$} & \multicolumn{2}{|c|}{$\begin{array}{l}\text { Caeruloplasmin } \\
(\mu \mathrm{g} / 100 \mathrm{ml})\end{array}$} \\
\hline & & & $\begin{array}{l}\text { Immuno- } \\
\text { logical }^{2}\end{array}$ & $\begin{array}{l}\text { Copper } \\
\text { oxidase }^{3}\end{array}$ \\
\hline $\begin{array}{l}\text { Retinitis pigmentosa } \\
\text { patients }(\mathrm{n}=38)\end{array}$ & $33 \cdot 9 / 8-66$ & $104 \pm 19$ & $35 \cdot 3 \pm 7 \cdot 3$ & $37 \cdot 0 \pm 7 \cdot 9$ \\
\hline $\begin{array}{l}\text { Family members } \\
(n=15)\end{array}$ & $40 \cdot 1 / 6-75$ & $113 \pm 16$ & $36 \cdot 4 \pm 5 \cdot 5$ & $41 \cdot 2=9 \cdot 5$ \\
\hline $\begin{array}{l}\text { Unrelated controls } \\
(\mathrm{n}=9)\end{array}$ & $29 \cdot 1 / 20-38$ & - & $28 \cdot 8 \pm 4 \cdot 8$ & $32 \cdot 3=7 \cdot 1$ \\
\hline
\end{tabular}

Serum values are mean \pm 1 SD. ${ }^{1}$ Lab normal range $=64-143$. ${ }^{2} \mathrm{Lab}$ normal range $=20-60$. ${ }^{3} \mathrm{Normal}$ range $22-43$ (O'Brien et al., 1968). Conversion = traditional units to SI: Copper $1 \mu \mathrm{g} / 100 \mathrm{ml}$ $=0.157 \mu \mathrm{mol} / \mathrm{l}$; Caeruloplasmin $1 \mathrm{mg} / 100 \mathrm{ml}=10 \mathrm{mg} / \mathrm{l}$ had somewhat higher caeruloplasmin values than our group of unrelated normals. This latter difference is of questionable significance, and the patients certainly did not show depressed caeruloplasmin levels, as in the Indian study, in which every patient value was below the lowest control. The lowest patient caeruloplasmin values we recorded were $22 \mathrm{mg} / 100 \mathrm{ml}(220 \mathrm{mg} / \mathrm{l})$ measured by the immunodiffusion technique, and $25 \mathrm{mg} / 100 \mathrm{ml}(250$ $\mathrm{mg} / \mathrm{l})$ measured by copper oxidase activity, both of which are within normal range.

The patients and family covered a broad range of ages, but Table 2 shows that there was no apparent relationship between age and either copper or caeruloplasmin values. The caeruloplasmin levels of patients were also compared on an individual basis with those from a related family member(s) to see whether a consistent difference might exist within each family if not within the group as a whole. No consistent variation could be found.

Elevated oestrogen levels, whether from pregnancy or exogenous medication, can raise both serum copper and caeruloplasmin (Schenker et al., 1972). Since medication histories were not available for all the women studied, we separated the serum copper and caeruloplasmin values by sex. Table 3 shows that the values from females ran slightly higher than those from males, but all were within the normal range and there were no significant differences

Table 2 Serum copper values by age

\begin{tabular}{|c|c|c|c|c|c|c|}
\hline & $\begin{array}{l}\text { Age } \\
n\end{array}$ & Group & Mean & $\begin{array}{l}\text { Copper } \\
(\mu \mathrm{g} / 100 \mathrm{ml})\end{array}$ & $\begin{array}{l}\text { Caeruloplasmi } \\
\text { Immunclogica }\end{array}$ & $\begin{array}{l}0 \mathrm{mll}) \\
\text { Copper oxidase }\end{array}$ \\
\hline \multirow[t]{3}{*}{ Patients: } & 9 & $<20$ & $13 \cdot 6$ & $101 \pm 15$ & $33 \cdot 6 \pm 6 \cdot 2$ & $36 \cdot 2 \pm 8 \cdot 8$ \\
\hline & 16 & $20-39$ & $30 \cdot 2$ & $103 \pm 20$ & $35 \cdot 3 \pm 8 \cdot 4$ & $37 \cdot 6 \pm 8 \cdot 6$ \\
\hline & 13 & $\geqslant 40$ & 52.5 & $108 \pm 21$ & $36 \cdot 6 \pm 6 \cdot 6$ & $36 \cdot 9 \pm 6 \cdot 9$ \\
\hline \multirow[t]{3}{*}{ Family: } & 3 & $<20$ & $9 \cdot 7$ & $110 \pm 28$ & $36 \cdot 7 \pm 9 \cdot 0$ & $41 \cdot 3 \pm 20 \cdot 0$ \\
\hline & 2 & $20-39$ & $28 \cdot 5$ & 111 & 36 & $40 \cdot 5$ \\
\hline & 10 & $\geqslant 40$ & $51 \cdot 5$ & $114 \pm 14$ & $36 \cdot 4 \pm 4 \cdot 6$ & $41 \cdot 4 \pm 6 \cdot 1$ \\
\hline
\end{tabular}

Table 3 Serum copper values by sex

\begin{tabular}{|c|c|c|c|c|c|}
\hline & & $\begin{array}{l}\text { Age } \\
\text { (mean) }\end{array}$ & $\begin{array}{l}\text { Copper } \\
(\mu \mathrm{g} / 100 \mathrm{ml})\end{array}$ & $\begin{array}{l}\text { Caeruloplasmin } \\
\text { Immunological }\end{array}$ & $\begin{array}{l}\text { ml) } \\
\text { Copper oxidase }\end{array}$ \\
\hline \multirow[t]{2}{*}{ Patients: } & 24 male & $31 \cdot 3$ & $98 \pm 15$ & $33 \cdot 2 \pm 5 \cdot 4$ & $34 \cdot 5 \pm 7 \cdot 0$ \\
\hline & 14 female & $38 \cdot 3$ & $116 \pm 20$ & $39 \cdot 0 \pm 8 \cdot 7$ & $41 \cdot 3 \pm 7 \cdot 6$ \\
\hline \multirow[t]{2}{*}{ Family: } & 5 male & 53.4 & $110 \pm 14$ & $35 \cdot 6 \pm 6 \cdot 0$ & $40 \cdot 4 \pm 6 \cdot 0$ \\
\hline & 10 female & 33.4 & $115 \pm 17$ & $36 \cdot 8 \pm 5 \cdot 5$ & $41 \cdot 7 \pm 11 \cdot 1$ \\
\hline \multirow[t]{2}{*}{ Controls: } & 6 male & $30 \cdot 5$ & $\longrightarrow$ & $28 \cdot 1 \pm 5 \cdot 2$ & $30 \cdot 8 \pm 8 \cdot 1$ \\
\hline & 3 female & $26 \cdot 3$ & - & $30 \cdot 0 \pm 4 \cdot 6$ & $35 \cdot 3 \pm 4 \cdot 0$ \\
\hline
\end{tabular}


Table 4 Serum copper values by inheritance pattern

\begin{tabular}{|c|c|c|c|c|c|}
\hline & & $\begin{array}{l}\text { Age } \\
\text { (mean) }\end{array}$ & $\begin{array}{l}\text { Copper } \\
(\mu g / 100 n: l)\end{array}$ & $\begin{array}{l}\text { Caeruloplasmin } \\
\text { Immunclogical }\end{array}$ & $\begin{array}{l}00 \mathrm{ml} \text { ) } \\
\text { Copper oxidase }\end{array}$ \\
\hline \multirow[t]{2}{*}{ Recessive: } & 21 patients & $39 \cdot 2$ & $103 \pm 16$ & $34 \cdot 7 \pm 7 \cdot 1$ & $36 \cdot 7 \pm 7 \cdot 7$ \\
\hline & 9 family members & $44 \cdot 3$ & $111 \pm 17$ & $34 \cdot 2 \pm 5 \cdot 5$ & $38 \cdot 7 \pm 8 \cdot 4$ \\
\hline \multirow[t]{2}{*}{ Dominant: } & 15 patients & $26 \cdot 7$ & $106 \pm 23$ & $36 \cdot 3 \pm 8 \cdot 0$ & $37 \cdot 7 \pm 8 \cdot 3$ \\
\hline & 4 family members & $29 \cdot 5$ & $117 \pm 19$ & $39 \cdot 5 \pm 4 \cdot 7$ & $45 \cdot 5 \pm 13 \cdot 1$ \\
\hline \multirow[t]{2}{*}{ X-linked: } & 2 male patients & 31 & 103 & $34 \cdot 5$ & 35 \\
\hline & 2 female carriers & 42 & 114 & 40 & 44 \\
\hline
\end{tabular}

Table 5 Urinary excretion of copper

\begin{tabular}{lllll}
\hline & & Sex & Age & 24-hour excretion $(\mu g)$ \\
\hline Recessive: & patient & M & 20 & 33 \\
& Patient & F & 28 & 25 \\
& Family & F & 25 & 23 \\
Dominant: patient & M & 16 & 22 \\
& Patient & F & 38 & 17 \\
& Family & F & 12 & 19 \\
X-linked: & patient & M & 36 & 9 \\
\hline
\end{tabular}

Normal for laboratory is $<50 \mu \mathrm{g} / 24$ hours

between affected and unaffected individuals. The values in all the tables exclude 5 women whose values were grossly elevated. Two were patients (aged 23 and 31) and 1 was a control (age 25) who were taking oestrogen-containing birth control pills. The other 2 were family members of which 1 (aged 22) was 7 months pregnant and the other (aged 53) took an oestrogen supplement. The serum copper of these five women ranged from 180 to $277 \mu \mathrm{g} /$ $100 \mathrm{ml}(28.3$ to $43.5 \mu \mathrm{mol} / \mathrm{l})$; the caeruloplasmin ranged from 59 to $80 \mathrm{mg} / 100 \mathrm{ml}(590$ to $800 \mathrm{mg} / \mathrm{l})$ by the immunodiffusion method and from 62 to $108 \mathrm{mg} / 100 \mathrm{ml}(620$ to $1080 \mathrm{mg} / \mathrm{l})$ by the copper oxidase method. This effect of oestrogens does not appear to be altered by retinitis pigmentosa.

Table 4 shows the data broken down by mode of inheritance. There are minor differences between the values in the different hereditary types, but there is no evidence that patient values are unusually high or low in any hereditary form of the disease. A recent report (Bastek et al., 1977) suggested that Xlinked patients may have serum copper levels in excess of carriers. In our $1 \mathrm{X}$-linked family grouping the patient's copper level of $115 \mu \mathrm{g} / 100 \mathrm{ml}(18 \cdot 1$ $\mu \mathrm{mol} / \mathrm{l})$ was between the values for 2 carriers in his family, namely, 108 and $120 \mu \mathrm{g} / 100 \mathrm{ml} \mathrm{(17.0} \mathrm{and}$ $18 \cdot 8 \mu \mathrm{mol} / \mathrm{l})$.

\section{URINARY EXCRETION OF COPPER}

The Indian study showed not only low caeruloplasmin in affected patients but elevation of the 24-hour excretion of copper levels near $200 \mu \mathrm{g}$. Table 5 shows the results of urinary copper measurements in 5 of our patients and 2 family members. All were well within the normal range of less than $50 \mu \mathrm{g} /$ 24 hours. Within this normal range the differences between hereditary types are probably of no significance.

\section{Discussion}

The report by Gahlot et al. (1976) on copper abnormalities in retinitis pigmentosa was striking because of the absolute nature of its results. Their patients all had caeruloplasmin values well below the normal range and below their set of control values, and had urinary excretion values several times the upper normal range. Thus the discrepancy between their results and ours is extreme. We found both patients and relatives of patients with retinitis pigmentosa to have values of serum copper, serum caeruloplasmin, and urinary excretion of copper that were indistinguishable from the normal population. Arrangement of the data by age, sex, hereditary type, or intrafamilial pairing failed to reveal any differences. Caeruloplasmin was normal whether measured immunologically or, as in the Indian study, by its diamino oxidase activity.

The proposition that copper metabolism is uniformly deranged in an unrelated group of retinitis pigmentosa patients seemed puzzling to us. Retinitis pigmentosa is probably a group of disorders involving several metabolic defects. No studies published to date have shown a universal systemic abnormality, whereas several retinal degenerations such as abetalipoproteinaema, Refsum's disease, and gyrate atrophy have been associated with a unique chemical defect. Theoretically, however, retinal degeneration from a variety of primary causes might itself produce a secondary metabolic change. Disorders of copper 
metabolism are rare in man, and have not been commonly associated with retinal degeneration (Ulmer, 1977). Copper deficiency in Menkes's syndrome can affect the retina, but the damage is primarily to the ganglion cells (Wray et al., 1976) and not to the photoreceptors, which are involved primarily in retinitis pigmentosa. The b-wave of the electroretinogram falls as Menkes's disease progresses, but the a-wave remains relatively well preserved (Levy et al., 1974).

Gahlot notes that his copper data from retinitis pigmentosa patients resemble the findings in patients with Wilson's disease. However, Wilson's disease (which involves a metabolic excess of copper) has been extensively studied, and retinal lesions are very rare, if relevant at all (Herron, 1976). Gahlot notes further that copper is required for pigmentation and suggests that retinitis pigmentosa is caused by a retinal pigmentary disturbance. Tryosinase, indeed, is a copper-containing enzyme (Riley, 1974), but the second part of the statement is arguable. Pigmentary changes in the fundus occur in a wide variety of degenerative conditions including not only retinitis pigmentosa but also peripheral uveitis, vascular occlusion, viral retinopathy, syphilis, etc. Most authors today view the pigmentation of retinitis pigmentosa (which represents migration of pigment into the retina) as a secondary phenomenon rather than the cause of the disease. Furthermore, there are many patients, especially in childhood, in whom severe functional changes are present (including an extinguished ERG) while the fundus is still unpigmented.

The reason for the difference between the Indian findings and our own remains obscure. Perhaps differences exist between the populations of the 2 nations. The normal values of the Indian study differ from American norms. Gahlot reports a mean caeruloplasmin in normals of $20 \cdot 1 \mathrm{mg} / 100 \mathrm{ml}$ $(201 \mathrm{mg} / \mathrm{l})$ whereas our average values for controls or patients ranged between 30 and $40 \mathrm{mg} / 100 \mathrm{ml}$ (300 and $400 \mathrm{mg} / \mathrm{l}$ ). In fact our lowest recorded caeruloplasmin levels were above the Indian norm. These discrepancies may be due to exogenous factors such as diet and overall nutrition or to genetic factors. Why patients with retinitis pigmentosa in the Indian population differed from normal subjects remains unclear. Possibly as a group they suffered greater deprivation of some exogenous factor. Possibly the Indian investigators were studying a genetic isolate of retinitis pigmentosa in which copper metabolism is deranged. Possibly retinitis pigmentosa involves a subtle copper defect which is not evident unless exogenous factors are also present.

Further study of the Indian patients will certainly be of great interest. Our results, however, suggest caution in drawing conclusions about the metabolic cause of retinitis pigmentosa. Copper metabolism appears to be normal in the typical American patient. Thus, we do not feel that any therapeutic proposals relative to copper metabolism should be considered at present.

\section{Addendum}

A report by Ehlers and Bülow (1977) has appeared since the submission of our paper showing that normal copper concentrations were also found in retinitis pigmentosa patients from Denmark.

Supported in part by National Eye Institute Grant EY-01678 (Dr Marmor). Special thanks are due to Mr John M. Weir, president of the local Retinitis Pigmentosa Foundation Chapter, who was instrumental in co-ordinating this study.

\section{References}

Bastek, J., Bogden, J., Cinotti, A., TenHove, W., Stevens, G., Markopoulos, M., and Charles, J. (1977). Trace metals in a family with sex-linked retinitis pigmentosa. Advances in Experimental Medicine and Biology, 77, 43-50.

Beale, R. N., and Croft, D. (1964). The microdetermination of biological copper with oxalyldihydrazide. Journal of Clinical Pathology, 17, 260-263.

Ehlers, N., and Bülow (1977). Clinical copper metabolism parameters in patients with retinitis pigmentosa and other tapeto-retinal degenerations. British Journal of Ophthalmology, 61, 595-596.

Gahlot, D. K., Khosla, P. K., Makashir, P. D., Vasuki, K., and Basu, N. (1976). Copper metabolism in retinitis pigmentosa. British Journal of Ophthalmology, 60, 770-774.

Herron, B. (1976). Wilson's disease. Ophthalmic Seminars, 1, 63-99.

Levy, N. S., Dawson, W. W., Rhodes, B. J., and Garnica, A. (1974). Ocular abnormalities in Menkes' kinky-hair syndrome. American Journal of Ophthalmology, 77, 319-325.

O'Brien, D., Ibbot, F. A., and Rogerson, D. O. (1968). Laboratory Manual of Pediatric Micro-biological Techniques, 4th edn., pp. 105-110. Harper \& Row: New York.

Riley, P. A. (1974). The biochemistry of pigment formation. In The Physiology and Pathophysiology of the Skin, pp. 1149-1165. Academic Press: New York.

Schenker, J. G., Jungreis, E., and Polishuk, W. Z. (1972). Oral contraceptives and correlation between serum copper and ceruloplasmin levels. International Journal of Fertility, 17, 28-32.

Ulmer, D. D. (1977). Trace Elements. New England Journal of Medicine, 297, 318-321.

Wray, S. H., Kuwabara, T., and Sanderson, P. (1976). Menkes' kinky hair disease: a light and electron microscopic study of the eye. Investigative Ophthalmology, 15, 128-138. 